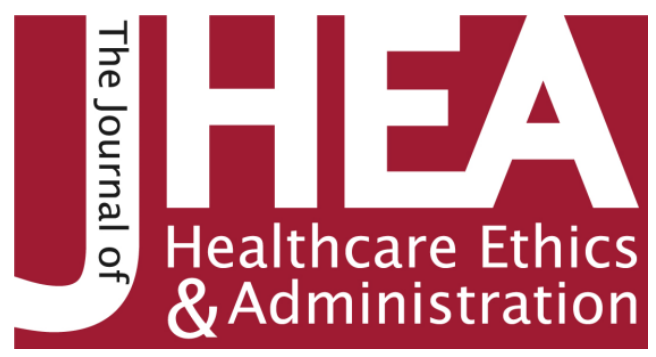

\title{
SPIRITUALITY AND ETHICS
}

\section{A Haiti Report: A Personal Reflection in Liberation Spirituality}

\author{
ALEXANDRE A. MARTINS, M.I., PH.D. \\ alexandre.martins@marquette.edu \\ Department of Theology, Marquette University, Milwaukee, U.S.A.
}

*Address correspondence to: Alexandre A. Martins, MI, Department of Theology, Marquette University, 1250 W. Wisconsin Ave, Milwaukee, WI 53233, U.S.A. E-mail: alexandre.martins@marquette.edu

Find this and more works at www.jheaonline.org

This work is brought to you for free and open access by the Institute of Clinical Bioethics (ICB) at Saint Joseph's University, Philadelphia, PA, U.S.A. It has been accepted for inclusion in The Journal of Healthcare Ethics \& Administration by editorial board and an authorized administrator of the JHEA. For more information, please contact support@jheaonline.org 


\title{
SPIRITUALITY AND ETHICS
}

\section{A Haiti Report: A Personal Reflection in Liberation Spirituality}

\author{
ALEXANDRE A. MARTINS, M.I., PH.D. \\ alexandre.martins@marquette.edu \\ Department of Theology, Marquette University, Milwaukee, U.S.A.
}

Keywords: Liberation spirituality, Haiti, suffering

I bless you, Father, Lord of heaven and of earth, for hiding these things from the learned and the clever and revealing them to little children.

Jesus (Matt 11:25)

I want a Church which is poor and for the poor.

They have much to teach us.

Not only do they share in the sensus fidei,

but in their difficulties they know the suffering Christ.

We need to let ourselves be evangelized by them.

Pope Francis, Evangelii Gaudium, no. 198

These two sentences have a deep impact on my life. The first one - together with another passage in which Jesus said that he was anointed by the Spirit of the Lord to proclaim the good-news to the poor (LK 4: 18) - became an existential inspiration in my human search for the truth among those who are excluded by an unjust and oppressive society. In addition, Jesus' preferential love for the poor, first fulfilled by his choice to live among them and to serve them as a partner, leads me to orient my life, whether in my existential choices, or in my social work, or in my academic investigations, based on the preferential option for the poor. I join the poor not only to offer them something (I really believe I do not have much to offer), but also to be with them as a companion, opening myself to learn from them and together to walk with them in a historical process of liberation, called by liberation theologians, the irruption of the poor in history.

In this account, I will present a reflection from my experience with Haitians during the months of July and August of 2016. These were times of kairós in which I received the gift of being welcomed among the incredible Haitian people and international professionals who work in Partners in Health. (My work in Haiti was possible because it was supported by the Theology Department of Marquette University and SOS DRS - Servants of St. Camillus - Disaster Relief Services.) When I sat down to write this paper, my intention was only to report my activities in Haiti through the Partners in Health' hospital in Mirabalais. But I decided to expand 
my goal and to begin with a personal reflection that arose from these days in Haiti. Therefore, before I present a report of my work, I am sharing some insights of my experience of companionship in Haiti.

\section{COMPANIONSHIP AND KNOWLEDGE}

Pope Francis emphasizes that the poor "have much to teach us." We can only learn from the poor if we have courage to be with them, seeing their faces, and listening to their voices. The poor have knowledge; they have something to teach us. In my first days in Haiti, I received an email from an American professor who had been in Haiti earlier. Before my trip, I had lunch with this professor and she shared that it was hard for her to stay more than one week in Haiti. She said: "It is a country with a lack of structure in which my profession has no value." Later in her email, she wrote: “Aren't the conditions there amazingly awful? But the people survive." It is true, they survive and she thought she couldn't survive more than one week nor had she anything to offer them. I risk saying that she could survive in Haiti if she had to. The poor Haitians survive in the middle of lack of structure and resources not because they want to, rather because they need to; there is no other option. They have to be creative to organize their lives from what they have in front of them. So they acquire a practical knowledge that helps them survive and sometimes goes beyond that, with moments of joy and hope. This professor would also realize that she could help them if she opened herself to be in the company of the poor, opening herself to learn from them in an experience of companionship.

Lack of humility of being in the company of the poor is a common mistake among people who go to do humanitarian work in poor countries. They see the poor as subjects of their noble action; that they have everything to offer and nothing to learn, or that the reality is too rough, nothing can be done to improve it, so it is better to leave without learning anything. These postures dismiss the power of the poor in history and their knowledge. This makes the purpose of humanitarian work for them, the peaceful conscience of activists, rather than the good of the poor, in a collaborative way.

The poor have a knowledge. It is not a scientific one. It is non-systematic, fragmented, and vulnerable to mistakes. However, it is a knowledge without it the poor could not survive in the world's misery. Their knowledge is not a systematic system. It is spread throughout their culture, traditions, habits, language, ways to address issues, beliefs, stories, and social organization. It has limitations, but nothing new here; science has also limitations. It is simple, but a simplicity full of meaning that cannot be dismissed or disrespected. In this simplicity lies its strength that gains expression in solidarity, resistance to oppression, and creativity to survive one more day in the middle of scarcity. Apart from them, seeing the poor leads us to question how they can survive? As the professor said, they do survive. This must lead us to think that they know something that we don't. This guides us to join them in a movement of companionship to learn from them what we don't know and, at the same time, providing them with what they do not have: establishing a process of mutual learning towards action for social justice.

\section{COMPANIONSHIP AND LIBERATION}

I believe that a true revolution and social transformation only occur from below, in a movement led by the oppressed and the poor. This does not exclude those who are not poor, but rather they must join the oppressed in an authentic option for the poor against their poverty. The option for the poor is not a choice for poverty, rather it is a movement for the dignity of the poor and their justice. The option for the poor is not a choice for the morality of the poor and oppressed. It is a choice for those who are victims of a system of exploitation that provides no opportunities. Among the poor, one finds attitudes that are not noble. However, the poor have no liberty because the mentality of those who hold the power also controls the minds of the oppressed. This situation causes the poor to want to leave poverty to be like the rich. The exploitation of the rich is camouflaged. It occurs through sophisticated mechanisms, such as the economic market. The rich, the oppressors, are not free either once their mentality is not motivated by what made them and the world fully human, but rather by what generates accumulation of more goods to support their status quo. Consequently, their humanity is enslaved by their search for goods, which is responsible for denying the humanity and the opportunity to flourish to those who are at the bottom, the poor. This up mentality is also present in the minds of the poor who use what they have to take advantage under any circumstances to achieve some improvement. Some even exploit the misery of their fellow poor. Others, unfortunately, go beyond and commit crimes. However, there is an experience of gathering among the poor that has almost disappeared among the oppressors, more and more dominated by a limitless desire for goods and individualism. They enjoy the benefits of this reality. Although the oppressors are not free, they enjoy a good life apart from those who sustain in abundance of an elite through their misery. This fat elite does not see the faces of those who are suffering because of the lack of essential goods; the same goods that are often wasted by this fat consumerist elite. Its members will never transform the society to benefit the poor. Real social transformation can only occur from those who are at the bottom and their partners who are among them in an existential commitment. However, the first step of this transformation begins with the liberation from the up mentality. Otherwise the poor will be impoverished, and only a few poor will leave their misery to participate in the fat elite. 
Haiti was the first Latin American/Caribbean country to be independent (1804). A nation built on the exploitation of men upon men: those who captured Africans to make them slaves in a new land to support the prosperity of a fat European elite. The blood of these black people shaped the basis for the only successful revolution of slaves in history. Courageous men and women fought for their freedom and to create an independent nation. They were victorious. A new free nation rose in the middle of the gorgeous waters of the Caribbean Sea. But history would not reserve for them the prosperity of an independent country. The fat elite, hurt in their pride by a rebellion of slaves, would not allow this noble black people to flourish as they deserve. Today, Haiti is still without its dream of liberty. The revolution that began from below did not work, and this small country is marked by violence, exploitation, coups, injustice, misery, natural disasters, and lack of resources. It is the poorest country in the Americas, being part of the poorest nations of the entire world. What was wrong with the revolution of slaves? Why are the rich (countries) never satisfied with how much they have and want to take away the little that the poor have?

Exploitation and violence have international and national dimensions. The people of Haiti have been victims of both dimensions. Perhaps the lack of freedom from up mentality is one of the reasons for this sad history that began with the hope of a rebellion from below. Without doubt, the achievement of freedom is necessary for the liberation of the poor in Haiti and elsewhere.

I arrived at Haiti without any pretension. I just wanted to share lives with the Haitians and be available to do whatever they see I can do to join forces and maybe help someone. I arrived in a beautiful night of full moon that blessed me and gave me a hug of encouragement. Her beauty was a contrast to precarious streets and the clear lack of structure. But, at the same time, this simplicity was the source of the moon's beauty and tenderness that cares for these suffering people and the revelation of God's preferential love for the poor.

It was my first time in Haiti. I didn't know what to expect there. I didn't know anybody. This trip was the realization of a desire that began a few years ago, precisely in 2010 after the earthquake that devastated this country. At that time, many factors prevented me from going there. Then my life turned to a direction that led me to opposite way from Haiti. I went to study in Boston, USA. There I met a physician, primarily reading one of his books and then personally, who led an organization with people serving in low-income countries. We began to build a friendly relationship. Four years after this meeting, I asked him if I could visit his work in Haiti. He immediately said yes. Dr. Paul Farmer and the Partners in Health have served in Haiti since the 1980s. They follow the principle of preferential option for the poor in health care. I arrived in Haiti with no a clear idea of what I could do. The only person I knew was not there and my Creole was zero. But as I said before, my main goal in Haiti was to share lives and to be in the company of the poor Haitians. I feel blessed to have had this opportunity, a life changing experience. I didn't want my time there to be only for me. I believe that I was there because of them, the Haitians, and that this time was my time given to them.

Paul Farmer and Gustavo Gutiérrez have a book whose title perfectly expresses its main idea: In the Company of the Poor. But what does this mean? They understand it to mean working among the poor. Many times, this means only to be with the poor in their suffering. A Brazilian bishop, Dom Luciano Mendes de Almeida, used to say that when we cannot do anything to help the poor, at least we can be with them. This idea of companionship has been very present in my life as a desire to be with the poor in their reality and their struggle. This brought me to Haiti, but it must go beyond this experience. Companionship with the poor must be a lifestyle in which I become a partner of the poor wherever I am, as the first existential realization of the preferential option for the poor.

Of course, being a person who had the opportunity to study and to develop certain skills, I want more then only being a companion. I also want to help the poor, to create justice, to see lives getting better, and to participate in the historical process of liberation. However, this must occur in a companionship way in which a person immerses into a new cultural identity. This requires a movement of courage: an immersion in the life of the poor through compassion from which arises solidarity to guide an action based on companionship. Therefore, the one who serves in a poor country becomes free and open to listen to the other, especially to those who are suffering. In the liberty of companionship, we act with courage, humility, and spontaneity, we understand our own frustrations and realize that sometimes we have only to be together with those who are suffering, and why not suffer with them? Hence, we do not provide only objective aid, but also hope, courage, and empowerment. In companionship, we do not want to save the world by ourselves, we do not want to keep people dependent on our services. Rather we work for their autonomy and independence. We become companions in the same existential journey, believing that we can work together for justice. Naturally, we become an insider, understanding the local worldview, and learning from it.

Slowly, I am learning the meaning of being in the company of the poor. I am learning the meaning of this perspective for social justice. With the Haitians, I learned the meaning of being in companionship with those, especially the poor, who have a worldview different from mine. This process begins only when one has the courage to leave his/her comfort zone to be with the poor and to see their faces.

\section{ACTIVITIES}


After this reflection on companionship, I will present a summary of activities I developed in Haiti. I spent 29 days in Haiti, the most part of the time in Mirabalais, a little village approximately 2 hours from Port-au-Prince. I joined the work developed by the NGO Partners in Health (PIH). This organization leads and supports healthcare actions in many parts of the country, especially in the rural area known as Central Plateau. PIH maintains the University Hospital of Mirabalais (UHM) that provides free healthcare assistance to a region of about 100,000 people. Idealized by Dr. Paul Farmer, co-founder of PIH, this hospital is also a teaching institution established to educate and empower Haitians, as health professionals, to be part of a process of caring and social justice in health care. I joined the hospital's activities; oriented to work with Fr. Eddy Eustache and his team. Fr. Eustache is also a psychologist who leads the Mental Health Department of UHM. As I said before, I went to Haiti without a clear plan of action. My connection with PIH was through my friendship with Paul Farmer who introduced me to Fr. Eustache. My first goal was to be in the companionship with Haitians and also to make myself available to work in any area, according to my skills. Since this was my first visit, I wanted to know better the reality and PIH's work. From this experience, new projects can be developed in the future.

The main goal of this experience with PIH was achieved, but I recognized that my time there would be better used if, with someone based in Mirabalais, I had developed a previous plan of actions. Although there was no clear plan, I engaged in some activities led by the hospital and organized by Fr. Eustache and his team.

Fr. Eustache and I created a plan of action. Knowing my education in Bioethics, Fr. Eustache worked with the medical residency programs and established a calendar of bioethical lectures for the residents and nurses of UHM. I delivered seven lectures at UHM to the health professionals of the following area: internal medicine, surgical medicine, emergency medicine, pediatrics, OB/GYN, oncologist nurses, and anesthesiologist nurses. Fifty-one professionals attended these lectures which were very well received. In addition, I delivered two lectures to the medical staff of Hospital Saint Nicolas in the city of Saint Marc, about three hours from Mirabalais, and one lecture to the psychology students of Notre Dame University in Cap-Haitian.

In these lectures, I focused on decision-making processes in health care, especially involving ethical dilemmas. I used discernment as the paradigm for my presentations. I encouraged health professionals to be attentive to all factors that affect their patients and the exercise of their profession, including clinical, social, and moral factors. I also encouraged professionals to present elements from their reality and practices to favor our discussion centered on their own context and issues. Based on concepts of the preferential for the poor in healthcare, solidarity, vulnerability, pragmatic solidarity, autonomy, structural violence, and the relationship between health and human rights, I also presented more socialized bioethics, and how this influences decision-making processes in health care.

I developed other activities as well. I accompanied the mental health team in some of its works, knowing its action outside the hospital supervising and orienting mental health professionals in other areas, especially in small rural clinics. I provided counseling to patients with huge suffering, drama, and terminal illness. I found some difficulty in doing this because of the language barrier. Even so, I was able to establish a good relationship with patients and their families.

I also joined community health workers and their visits to sick people in their homes. This was a great experience to see the reality of those who live in distant rural areas and who have enormous difficult to leave their homes and go to the hospital. Joining the health workers, visiting families and attending one of their agenda meetings, was an opportunity to understand their community-based approach of delivering health care.

During the weekends, I had free time from the hospital to join local Haitians from different contexts. Hence, I spent time with the local Catholic priest learning about his work with the local community. I spent one weekend in Port-au-Prince with the kids of Zanmi Beni. And I went to Cap-Haitian with Fr. Eustache to learn about his work there. All these experiences were precious opportunities to get to know a little bit more about the Haitian culture, the local reality, and learning from the Haitians.

I traveled to Haiti with the desire to have an experience of companionship with the Haitian people. I knew I didn't have much to offer and I had much to learn. With me, I brought a message of God's love for the poor who, according to Jesus, are the privileged recipients of the gospel (LK 4:18). I wanted to help without making people objects of my action, but rather being a companion in an experience of mutual learning. I chose to do this experience with the Partners in Health because through their pragmatic solidarity, they believe in the preferential option for the poor. This organization does so much for the Haitian people, and these beautiful people did so much for me while we were together in companionship; perhaps this time was first step of a long relationship. 